\title{
Improving Students' Science Process Skills for Material of Forces Through the Contextual Teaching Learning Model (CTL) in Elementary School
}

\author{
Julhidayat Muhsam $^{1,2 *}$, Muhammad R. Letasado ${ }^{1}$ \\ ${ }^{1}$ Muhammadiyah University Kupang, Kupang, Indonesia \\ ${ }^{2}$ Muhammadiyah University Kupang, Kupang, Indonesia \\ *Corresponding author :julhidayat.1.muhsam@gmail.com
}

\begin{abstract}
Science process skill is an important aspect in learning natural science. However, previous studies revealed that students' science process skills were still low so that various efforts are needed to improve it. One of the efforts to be done is implementing a learning model that can facilitate these skills is Contextual Teaching and Learning (CTL). This study aims to improve students' science process skills through the CTL learning model. This research used a CAR design. The population were 74 elementary students, while the samples consisted of 26 students determined using random sampling technique. Data collection techniques used documentation, tests, and observations carried out in each action. The results of round 1 for the components of observation was $82 \%$, categorization was $43 \%$, measurement was $40 \%$, interpretation was $48 \%$, prediction was $46 \%$, application was $46 \%$, planning was $53 \%$, and communication was $80 \%$. The percentage of mastery learning in round 2 for the component of observation was $94 \%$, categorization was $84 \%$, measurement was $85 \%$, interpretation was $88 \%$, prediction was $89 \%$, application was $87 \%$, planning was $84 \%$, and communication was $88 \%$. Therefore, it can be concluded CTL model was able to improve students' science process skills on material of forces.
\end{abstract}

Keywords: science process skills, CTL

\section{INTRODUCTION}

Today education has become a primary need for every human being, including in Indonesia. This is because education plays an important role in creating quality Indonesian human resources (HR). Human resources are needed to build a country into a prosperous country [1].

Realizing quality education requires ongoing efforts to improve the quality of education [2]. Improvements have been made in the components of the education system namely curriculum, learning strategies, learning aids, learning resources, etc. To improve the quality of education, the government develop the curriculum from School-Based Curriculum to the 2013 Curriculum. The 2013 curriculum focuses on forming attitudes and life skills. The low scientific ability of students is influenced by various factors, including the curriculum and education system, the selection of teaching methods and models by teachers, learning facilities, learning resources, etc. [3].

From the result of direct observation, some teachers remain using conventional learning method. The method applied by the teacher in the class is less varied so that it is unable to develop students' science process skills. The performance of students in participating in science learning is still low which is marked by the lack of active students in answering questions raised by teachers, students are less active in asking questions, and lack of student initiative during learning [4].

Science process skills are all directed scientific skills (both cognitive and psychomotor) that can be used to find a concept, principle or theory to develop pre-existing concepts [5]. The aspects of basic science process skills that students need to have are as follows; 1) observing, 2) interpreting observations, 3) predicting, 4) using tools and materials, 5) applying concepts, 6) planning research, 7) communicating, 8) asking questions [6].

Process skills in the field of natural science are knowledge of concepts in principles that can be obtained by students if they have certain basic abilities such as science process skills [7]. Therefore, science process skills need to be trained to make students be able to master the skills to carry out observation and experimental activities in order to develop the concept of science [8].

These findings indicate that learning science in primary schools has not yet fully facilitated science process skills. The lack of science process skills is one of the urgent problems that must be immediately resolved in the science learning process [9]. One effort to improve students' science process skill is to utilize more innovative learning models and make students more active. An alternative to overcome these problems is to use the Contextual Teaching and Learning (CTL) model. CTL is a learning concept in which the teacher presents real-world situations in the classroom and encourages students to make 
connections between their knowledge and its application in life, while students acquire knowledge little by little, and from the process of constructing themselves, as a provision to solve problems in their life [10]. In other words, CTL as a learning model can be used to make the implementation of the curriculum effective and successful, where this learning emphasizes the relationship between learning material and the student's life in real world, so that students are able to connect and apply competency learning outcomes in everyday life. CTL is also a system that stimulates the brain to compose patterns to produce meaning by connecting academic content with the context of students' daily lives [11].

CTL model allows students to associate the contents of academic subjects with the context of everyday life to find meaning. Something is considered meaningful because it meets the needs, attracts interest, is important for further study, for the completion of work assignments, or for the future [12]. CTL learning can broaden the personal context of students through providing fresh experiences that will stimulate the brain to establish new relationships to get new meaning further [13]. Seven main components of contextual learning include: constructivism, questioning, inquiry, learning community, modeling, and authentic assessment [14].

Strategies in learning CTL are emphasizing problem solving, realizing that teaching and learning should take place in a variety of contexts such as teaching students to monitor and direct their own learning, linking teaching to the lives of different learners' contexts, encouraging students to learn from fellow peers, and applying authentic assessment [15]. The advantage of the CTL model is that it helps students comprehensively understand the meaning of learning material by involving the relationships of everyday life, thus making students have the knowledge or skills that are appropriate to the situation based on self-understanding.

The learning process using CTL must consider the following characteristics: 1) cooperation; 2) support each other; 3) fun and not boring; 4) study with passion; 5) integrated learning; 6) using multiple sources; 7) active students; 8) sharing with friends; 9) creative teacher and critical students; 10) classroom walls and hallways filled with student work (maps, pictures, articles); 11) reports to parents are not only report cards, but student work, practicum reports, student essays, and others [16].

\section{RESEARCH METHODOLOGY}

There were 26 students in this study. The factor studied was the students' science process skills as measured through the test item of science process skills. This study used a CAR design done in two cycles. The flow of action in this CAR was described by Kemmis \& Taggart [17].

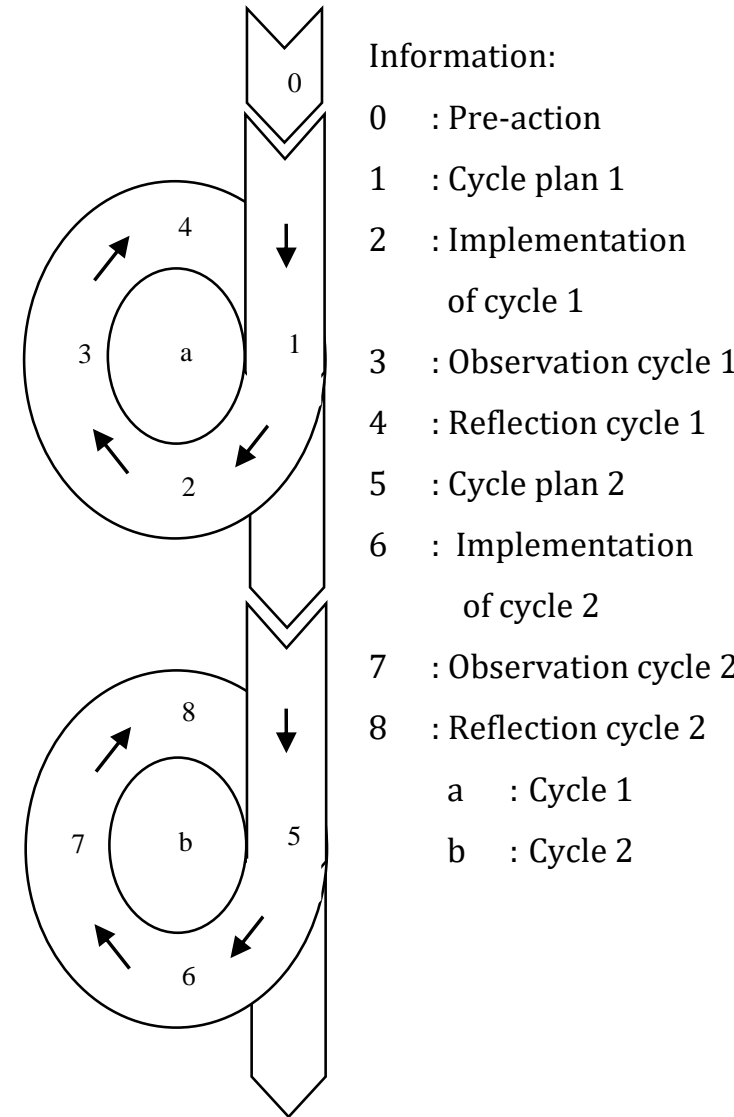

Figure 1. The flow of CAR Model by Kemmis \& McTaggart

This research consisted of the pre-action phase and the action phase.

1. Pre-Action Stage:

a) Initial ability checking test: The activity undertaken is to provide a preliminary test to determine the abilities possessed by students before the application of the Numbered Heads cooperative learning model. The results of this test are also used as the initial value needed in managing the value of improvement.

b) Formation of study groups: This activity begins with selecting smart students as the expert group (chairman) and grouping other students according to sequence and grouping with the same number. Then join the expert group.

2. Implementing action stage:

a. Scheduling: scheduling learning sketches by including the CTL learning model and dividing into groups (5) heterogeneously so that students work with each other in teams during the learning process.

b. Implementation: Implementation of learning with the CTL model, including introduction, core learning, and closing. 
c. Observation: Observation results were discussed with the observer team. At the end of the first action, the effects of applying the CTL learning model were described.

d. Analysis: The results of the analysis presented a description of the effect of the activities carried out. If the students are not successful, the investigation will be carried out again through round 2 .

Data collection used documentation of related data, tests, and observations made in each action. The data that has been collected were then processed using a number of statistical equations. To find out the improvement of students' science process skills through the application of the CTL learning model, the researchers conducted a data analysis of absorption calculation by using the following formula:

$$
\text { Absorption }=\frac{\text { Number of students answer correctly }}{\text { Total Number of Students }} X 100
$$

Table 1. Criteria for the success of the action

\begin{tabular}{ll}
\hline \multicolumn{1}{c}{ Value } & \multicolumn{1}{c}{ Category } \\
\hline $75 \%<\mathrm{NR} \leq 100 \%$ & $=$ Very Good \\
$50 \%<\mathrm{NR} \leq 75 \%$ & $=$ Good \\
$25 \%<\mathrm{NR} \leq 50 \%$ & $=$ Good enough \\
$0 \%<\mathrm{NR} \leq 25 \%$ & $=$ Not good enough \\
\hline
\end{tabular}

\section{RESULT AND DISCUSSION}

\subsection{Analysis of the Result of Cycle I}

In the first action, the average science process skill ability of students has not yet been reached. This can be seen from the completeness data of learning outcomes, especially the science process skills of students who on average were still incomplete. The details can be seen in Figure 1.

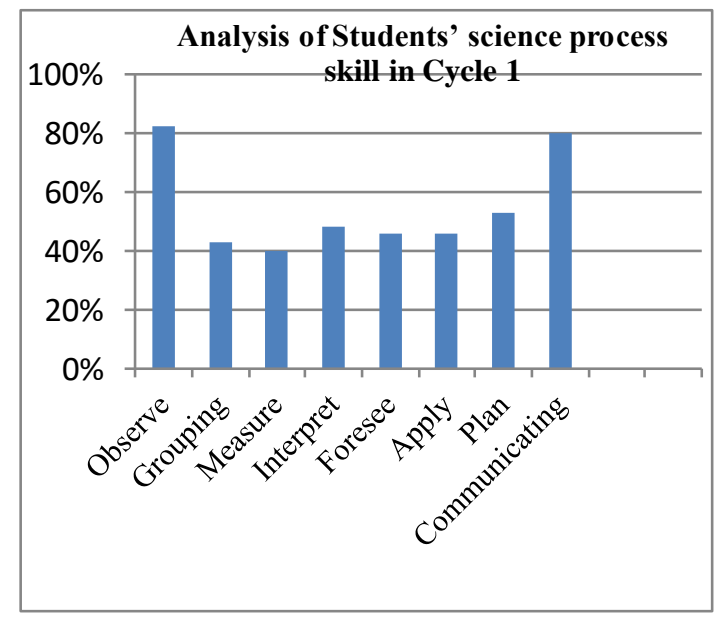

Figure 2. Analysis of Students' science proces skill in cycle 1
Diagram 1 shows that the items that were able to be absorbed for the component of observation reached $82 \%$, categorization reached $43 \%$, the measurement reached $40 \%$, interpretation reached $48 \%$, prediction reached $46 \%$, implementation reached $46 \%$, planning reached $53 \%$, and communication reached $80 \%$. Thus, it can be concluded that the number of items in the students' science process skills in Cycle I that have been mastered were only two aspects.

The inability of students to achieve learning targets in the first cycle was caused by some weaknesses, including: 1) Students were not familiar with items about science process skills; 2) The teacher has not been able to streamline time according to the demands in the CTL syntaxes. Therefore, it could be overcome in Cycle II. It was expected that students' inability to master the components of the science process skills in Cycle I would be achieved in Cycle II.

\subsection{Description of Data in Cycle 2}

In cycle II, the learning outcomes of students' science process skills were very good. This can be seen from the data of completeness of learning outcomes in science process skills. The detailed data can be seen in Figure 2:

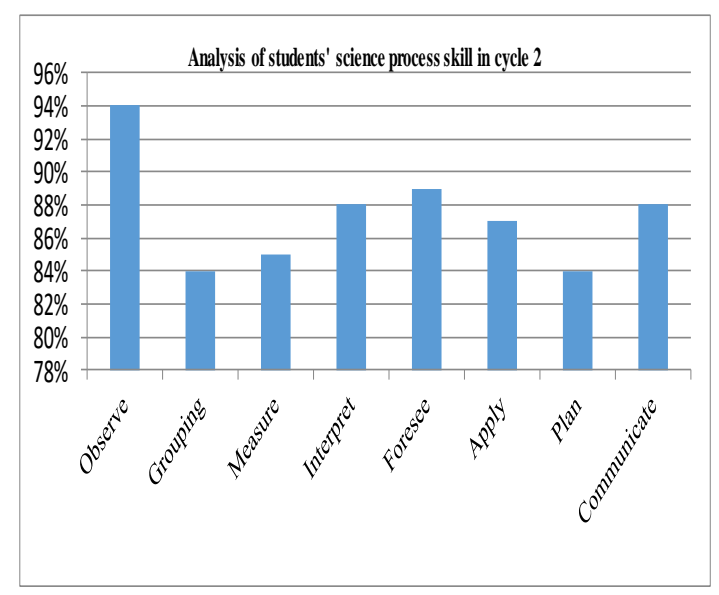

Figure 3. Analysis of Students' science proces skill in cycle 2

Diagram 2 that the items absorbed for the component of observation reached $94 \%$, categorization reached $84 \%$, measurement reached $85 \%$, interpretation reached $88 \%$, prediction reached $89 \%$, application reached $87 \%$, planning reached $84 \%$, and communication reached $88 \%$. Thus, $\mathrm{t}$ can be said that the number of items in the science process skills of students in Cycle II has been completed individually or classically, so there was no need for repetition.

\section{CONCLUSION}

Based on the results of the analysis of students 'science process skills tests in the first cycle and the second cycle, CTL can improve students' science process skills. This can be seen from the results of the science process skills test of students in the first cycle that only two components of process skills were completed. Thus, those components were repeated in 
cycle II. Furthermore, more optimal preparation and planning of the second cycle have made all students were able to complete the components of science process skills. Therefore, the second cycle were not needed for repetition. The improvement of students' science process skills shows that CTL can be a suitable model for improving science process skills. This is because of the nature of CTL as a learning model which brings students to build their own knowledge through their active involvement in the learning process [19]. CTL learning can also be the basis for building students' cognitive, affective, and psychomotor abilities, where all three elements are found in aspects of science process skills, namely observation, categorization, measurement, interpretation, prediction, implementation, planning research, and communication.

\section{REFERENCES}

[1] Novita, dkk. 2014. Pengaruh Model Pembelajaran Pbl Terhadap Keterampilan Proses Sains Siswa Kelas V SD Di Gugus IV Diponegoro Kecamatan Mendoyo. Jurnal Mimbar PGSD Universitas Pendidikan Ganesha. Jurusan PGSD (Vol: 2 No: 1 Tahun 2014)

[2] Haryono, dkk. 2012. "Model MFI dan POGIL Ditinjau Dari Aktifitas Belajar dan Kretivitas Siswa Terhadap Prestasi Belajar". Prosiding ISSN: 2252-7893

[3] Widiawati, Ika. 2014. "Upaya Meningkatkan Keterampilan Proses Sains Siswa Melalui Strategi Pembelajaran POGIL pada Materi Laju Reaksi Di Kelas XI SMA Negeri 36 Jakarta". Jakarta: Universitas Negeri Jakarta.

[4] Ningsih, dk. 2015. Pengaruh Metode Pogil (Process Oriented Guided Inquiry Learning) Terhadap Keterampilan Proses Sains Siswa Pada Materi Suhu dan Kalor Kelas X SMA. Prosiding Seminar Nasional Fisika (E-Journal) SNF2015. p-ISSN: 2339-0654 e-ISSN: 24769398

[5] Trianto. (2008). Mendesain Pembelajaran Kontekstual (Contextual Teaching And Learning) Di Kelas. Surabaya: Cerdas Pustaka

[6] Nuryani, YR. (2007). Keterampilan Proses Sains. Diklat Ajar, Bandung: UPI Bandung.

[7] Hamalik, O. 2005. Kurikulum dan Pembelajaran. PT bumi Aksara. Jakarta.

[8] Ibrahim, Muslimin. 2010. Dasar-Dasar Proses Belajar Mengajar. Surabaya: Unesab University Press
[9] Riyadi, I.P., Prayitno, B.A., \& Marjono. (2015). Implementation of Guided Inquiry in Coordination System Material to Improve Science Process Skill at Class XI IPA 3 Students in SMA Batik 2 Surakarta in Academic Year 2013/2014. Jurnal Pendidikan Biologi, 7(2), 80-93.

[10] Zulaiha. 2016. Pendekatan Contextual Teaching And Learning (CTL) dan Implementasinya dalam Rencana Pembelajaran PAI MI. Jurnal Pendidikan Islam. Vol. 1, no 01, 2016 | p-ISSN 25483390; e-ISSN 2548-3404

[11] Rusyida, W.Y., Mohammad Asikin., \& Edy Soedjoko. 2013. Komparasi Model Pembelajaran CTL dan Mea terhadap Kemampuan Pemecahan Masalah Materi Lingkaran. Journal of Mathematics Education 2 (1) (2013). ISSN 2252-6927

[12] Sukmadinata, NS dan Syaodih, E. (2012). Kurikulum dan Pembelajaran Kompetensi. Bandung: PT Refika Aditama.

[13] Johnson, EB. (2009). Contextual Teaching and Learning, Menjadikan Kegiatan Belajar Mengajar Mengasyikkan dan Bermakna. Bandung: Mizan Media Utama

[14] Trianto. 2014. Mendesain Model Pembelajaran Inovatif, Progresif, dan Kontekstual (Konsep, Landasan, dan Implementasinya pada Kurikulum 2013).Jakarta:PT Kharisma Putra Utama.ISBN 978-602-1186-05-3

[15] Wartono. 2003. Strategi belajar mengajar fisika. Malang: Erlangga

[16] Rusman. 2016. Model-Model Pembelajaran: Mengembangkan Profesionalisme Guru. Jakarta. PT Raja Grafindo Persada. ISBN 978979-769-460-9

[17] Julhidayat, dk. 2020. Penerapan Model Pembelajaran Contextual Teaching Learning (CTL) pada Materi Gaya bagi Siswa Kelas 4 Sekolah Dasar. Jurnal Elementary. ISSN 2614- 5596. Vol. 3 No. 2 Juni 2020, hal. $53-57$

[18] Dantes. 2017. Desain Eksperimen dan Analisis Data. Depok: PT Raja Grafindo Persada. ISBN 978-602-425- 198-7. dst.

[19] Trianto. 2009. Mendesain Model Pembelajaran Inovatif-Progresif. Surabaya: Kencana 